Research Article

\title{
Genetic divergence between Melipona quadrifasciata Lepeletier (Hymenoptera, Apidae) populations
}

\author{
Mara Garcia Tavares, Nathalia Teixeira Pietrani, Maxwell de Castro Durvale, Helder Canto Resende \\ and Lucio Antonio de Oliveira Campos
}

Departamento de Biologia Geral, Universidade Federal de Viçosa, Viçosa, MG, Brazil.

\begin{abstract}
Melipona quadrifasciata is a stingless bee widely found throughout the Brazilian territory, with two recognized subspecies, M. quadrifasciata anthidioides, that exhibits interrupted metasomal stripes, and M. quadrifasciata quadrifasciata, with continuous metasomal stripes. This study aimed to estimate the genetic variability of these subspecies. For this purpose, 127 colonies from 15 Brazilian localities were analyzed, using nine species-specific microsatellite primers. At these loci, the number of alleles ranged from three to 15 (mean: 7.2), and the observed heterozygosity $\left(\mathrm{H}_{0}\right)$ ranged from 0.03-0.21, while the expected heterozygosity $\left(\mathrm{H}_{\mathrm{e}}\right)$ ranged from $0.23-0.47$. The genetic distances among populations ranged from 0.03-0.45. The $F_{S T}$ multilocus value $(0.23)$ indicated that the populations sampled were structured, and the clustering analysis showed the formation of two subgroups and two more distant populations. The first group contained the subspecies $M$. quadrifasciata quadrifasciata, and the other, the subspecies $M$. quadrifasciata anthidioides and the two $M$. quadrifasciata populations with continuous metasomal stripes from northern Minas Gerais. These results confirmed that the yellow metasomal stripes alone are not a good means for correctly identifying the different subspecies of $M$. quadrifasciata.
\end{abstract}

Keywords: genetic differentiation, microsatellites, population genetics, stingless bees.

Received: May 2, 2012; Accepted: August 13, 2012.

\section{Introduction}

Despite their ecological importance as pollinators of native trees in Brazil (Kerr et al., 2001; Imperatriz-Fonseca et al., 2006), stingless bee populations have decreased in the Neotropics, similarly to other bee populations, due to habitat degradation and fragmentation, agricultural intensification, indiscriminate use of agrochemicals and pesticides, and introduction/spread of exotic species (Freitas et al., 2009).

Melipona quadrifasciata, in particular, is a stingless bee species with a wide geographic distribution in Brazil (Silveira et al., 2002; revised in Camargo and Pedro, 2007). Few molecular studies, however, have been conducted on this species to analyze its genetic variability and structuring of populations (Waldschmidt et al., 2000, 2002; Moreto and Arias, 2005; Souza et al., 2008; Batalha-Filho et al., 2009, 2010; Nascimento et al., 2010).

In general, these studies have provided evidence that it is possible to recognize molecular differences between the two M. quadrifasciata subspecies, confirming the usefulness of the yellow metasomal stripes, which are continuous in M. quadrifasciata quadrifasciata and interrupted in

Send correspondence to Mara Garcia Tavares. Departamento de Biologia Geral, Universidade Federal de Viçosa, 36570-000 Viçosa, MG, Brazil. E-mail: mtavares@ufv.br.
M. quadrifasciata anthidioides, to distinguish them (Schwarz, 1932).

However, according to Moure and Kerr (1950), although M. quadrifasciata quadrifasciata is found in the colder regions located from Rio Grande do Sul to southern São Paulo, and M. quadrifasciata anthidioides occurs from northeastern São Paulo along eastern Brazil up to Paraíba, a hybridization zone exists in the states of São Paulo and Minas Gerais, with specimens presenting an intermediary pattern of yellow metasomal stripes.

More recently, M. quadrifasciata individuals from Januária and Urucuia (northern Minas Gerais) have been observed exhibiting continuous metasomal stripes identical to those of M. quadrifasciata quadrifasciata instead of the interrupted pattern characteristic to $M$. quadrifasciata anthidioides, as was expected based on their geographical localization (review in Batalha-Filho et al., 2009). The specimens from Januária, however, did not exhibit the RAPD marker present in individuals of the subspecies $M$. quadrifasciata quadrifasciata, being therefore genetically more similar to $M$. quadrifasciata anthidioides (Waldschmidt et al., 2000).

Another population bearing a continuous pattern of metasomal stripes was later on described in Sergipe and northeastern Bahia (Batalha-Filho et al., 2009). RFLP analysis and sequencing of the mtDNA COI gene again demon- 
strated that this population grouped together with populations from northern Minas Gerais and populations of M. quadrifasciata anthidioides (Batalha-Filho et al., 2010).

These data demonstrate that a distinction between $M$. quadrifasciata anthidioides and $M$. quadrifasciata quadrifasciata based exclusively on morphological characteristics is not reliable.

Thus, the main objective of this study was to investigate the genetic variability of some $M$. quadrifasciata populations from different locations in Brazil, in order to improve the knowledge about their taxonomic status.

\section{Materials and Methods}

\section{Bee samples}

Melipona quadrifasciata adult workers from 127 colonies were collected in eight Brazilian states. $M$. quadrifasciata quadrifasciata samples were collected in the states of Rio Grande do Sul (Porto Alegre), Santa Catarina (Içara) and Paraná (Curitiba), while $M$. quadrifasciata anthidioides samples were obtained in Rio de Janeiro (Miguel Pereira), Minas Gerais (Cristiano Otoni, Piranga, Caeté, Rio Vermelho and Poté), Espírito Santo (Domingos Martins) and Bahia (Caitité). We also included samples from Urucuia/Januária and São Cristovão in the analyses, representing $M$. quadrifasciata populations with continuous metasomal stripes from northern Minas Gerais and Sergipe, respectively. It is important to emphasize that these populations were located completely outside the distribution area of $M$. quadrifasciata quadrifasciata which typically exhibits continuous yellow metasomal stripes.
Samples from Ourolândia (Bahia) presenting a hybrid pattern of metasomal stripes were also analyzed.

Samples from Cristiano Otoni, Caeté, Urucuia and Januária were collected from feral colonies, directly from nature. Samples from Piranga, Rio Vermelho, Poté, São Cristovão, Ourolândia and Caitité were provided by beekeepers that maintain a small number of colonies in the original trunks or in rational boxes. These colonies were collected in their propriety wood or in the neighborhood, approximately 500-1000 $\mathrm{m}$ from their present-day localization. Samples from Domingos Martins, Miguel Pereira, Içara, Porto Alegre and Curitiba were obtained from colonies kept in local meliponaries. These colonies, however, were also obtained from the respective regions and did not represent translocated colonies.

The geographic distribution and the number of colonies sampled in each locality are shown in Table 1. Samples were stored in absolute ethanol at $-80{ }^{\circ} \mathrm{C}$ until DNA extraction.

\section{DNA extraction and amplification}

Genomic DNA from 127 individuals (one per colony) was extracted according to the protocol of Waldschmidt et al. (1997) and amplified using nine microsatellite primers specifically designed for M. quadrifasciata in our laboratory (Table 2).

To perform the amplification, the forward (F) sequence of each primer was modified at the 5 ' end with the addition of a sequence of the M13 universal primer (5'-TTTTCCCAGTCACGA-3') (Schuelke, 2000). Additionally, the M13 universal primer was labeled with a fluo-

Table 1 - Sampled localities, geographic coordinates and number of Melipona quadrifasciata colonies $(\mathrm{N})$ analyzed.

\begin{tabular}{llll}
\hline Subspecies & Locality/State (code) & Coordinates & N \\
\hline M. q. quadrifasciata & Porto Alegre/RS (PA) & $30^{\circ} 01^{\prime} \mathrm{S} ; 5^{\circ} 13^{\prime} \mathrm{W}$ & 5 \\
& Içara/SC (IÇ) & $28^{\circ} 42^{\prime} \mathrm{S} ; 49^{\circ} 17^{\prime} \mathrm{W}$ & 5 \\
& Curitiba/PR (CT) & $25^{\circ} 25^{\prime} \mathrm{S} ; 49^{\circ} 16^{\prime} \mathrm{W}$ & 18 \\
\hline M. q. anthidioides & Miguel Pereira/RJ (MP) & $22^{\circ} 27^{\prime} \mathrm{S} ; 43^{\circ} 28^{\prime} \mathrm{W}$ & 4 \\
& Cristiano Otoni/MG (CO) & $20^{\circ} 51^{\prime} \mathrm{S} ; 43^{\circ} 45^{\prime} \mathrm{W}$ & 8 \\
& Piranga/MG (PI) & $20^{\circ} 36^{\prime} \mathrm{S} ; 43^{\circ} 11^{\prime} \mathrm{W}$ & 9 \\
& Domingos Martins/ES (DM) & $20^{\circ} 23^{\prime} \mathrm{S} ; 41^{\circ} 01^{\prime} \mathrm{W}$ & 6 \\
& Caeté/MG (CE) & $19^{\circ} 48^{\prime} \mathrm{S} ; 43^{\circ} 32^{\prime} \mathrm{W}$ & 15 \\
& Rio Vermelho/MG (RV) & $18^{\circ} 18^{\prime} \mathrm{S} ; 43^{\circ} 00^{\prime} \mathrm{W}$ & 7 \\
& Poté/MG (PO) & $17^{\circ} 46^{\prime} \mathrm{S} ; 41^{\circ} 54^{\prime} \mathrm{W}$ & 3 \\
& Caitité/BA (CA) & $14^{\circ} 03^{\prime} \mathrm{S} ; 42^{\circ} 29^{\prime} \mathrm{W}$ & 7 \\
\hline M. q. anthidioides ${ }^{*}$ & Urucuia/MG (UR) & $16^{\circ} 04^{\prime} \mathrm{S} ; 45^{\circ} 47^{\prime} \mathrm{W}$ & 15 \\
& Januária/MG (JA) & $15^{\circ} 25^{\prime} \mathrm{S} ; 44^{\circ} 19^{\prime} \mathrm{W}$ & 13 \\
& São Cristovão/SE (SC) & $11^{\circ} 01^{\prime} \mathrm{S} ; 37^{\circ} 12^{\prime} \mathrm{W}$ & 4 \\
\hline $\begin{array}{l}\text { M. quadrifasciata } \text { with a hybrid } \\
\text { pattern of tergal stripes }\end{array}$ & Ourolândia/BA (OU) & $10^{\circ} 58^{\prime} \mathrm{S} ; 41^{\circ} 04^{\prime} \mathrm{W}$ & 8 \\
\hline
\end{tabular}

*M. quadrifasciata anthidioides with continuous tergal stripes. 
Table 2 - Characteristics of the nine microsatellite loci of Melipona quadrifasciata used in the present study.

\begin{tabular}{|c|c|c|c|c|c|}
\hline Locus & Repeat motif & Primer sequences $\left(5^{\prime}-3^{\prime}\right)$ & $\mathrm{Ta}\left({ }^{\circ} \mathrm{C}\right)$ & Allele size range (bp) & $\mathrm{k}$ \\
\hline Mquad2 & $(\mathrm{TGC})_{4}(\mathrm{CGC})_{4}$ & $\begin{array}{l}\text { F: GTGCTCTTGCTCTTGCTC } \\
\text { R: CCGCAGTTTTTGTTCGCCT }\end{array}$ & 55 & $142-151$ & 4 \\
\hline Mquad4 & $(\mathrm{GC})_{5}$ & $\begin{array}{l}\text { F: CGCTGACTTTAAAATCGTTC } \\
\text { R: TCGCTTCTGTTCGTTCTC }\end{array}$ & 55 & $121-153$ & 6 \\
\hline Mquad5 & $(\mathrm{ATT})_{6}$ & $\begin{array}{l}\text { F: TGAAATCCAGAAATCTTATG } \\
\text { R: TCGTTCGGTTTGGTAATG }\end{array}$ & 55 & $124-130$ & 5 \\
\hline Mquad6 & $(\mathrm{TAT})_{7}$ & $\begin{array}{l}\text { F: TCAGAGAACAGACCCAATC } \\
\text { R: GGACCTAATACCTGCACT }\end{array}$ & 55 & $112-148$ & 8 \\
\hline Mquad7 & $(\mathrm{AT})_{21}$ & $\begin{array}{l}\text { F: CGCACACGCTAACGGAACG } \\
\text { R: CAGGACGAGGCGTAACCG }\end{array}$ & 65 & $131-185$ & 15 \\
\hline Mquad13 & $(\mathrm{AATCGC})_{2}$ & $\begin{array}{l}\text { F: GGAGGATCCTCTCGACGAGG } \\
\text { R: GGTTCCCGAAACGTGCACCC }\end{array}$ & 65 & $182-248$ & 8 \\
\hline Mquad19 & $(\mathrm{TC})_{8}$ & $\begin{array}{l}\text { F: GGGACGCACGATCTCGGACG } \\
\text { R: GGACACGCCCGTGGGAAGAG }\end{array}$ & 65 & 120-194 & 11 \\
\hline Mquad20 & $(\mathrm{GGACG})_{5}$ & $\begin{array}{l}\text { F: CGTGACGGGATAATCCTTGC } \\
\text { R: TCACCGAGCCTGTTTTCAGG }\end{array}$ & 60 & $189-234$ & 5 \\
\hline Mquad24 & $(\mathrm{GA})_{8}$ & $\begin{array}{l}\text { F: ACGCGCACGCGCACACATAC } \\
\text { R: CGCGCGTCGCTGACTCATGC }\end{array}$ & 67 & $144-146$ & 3 \\
\hline
\end{tabular}

F and R: forward and reverse primers, respectively; Ta: annealing temperature; k: number of alleles.

rescent dye (FAM-6-carboxy-fluorescein or HEX hexacloro-6-carboxy-fluorescein).

The amplification reaction solutions consisted of 10 ng DNA, $200 \mu \mathrm{M}$ of each dNTP, $1.0 \mu \mathrm{M}$ of each primer (F, R and M13), $1.5 \mathrm{mM} \mathrm{MgCl}_{2}$, and 0.5 unit of Platinum Taq polymerase (Invitrogen) in 10x buffer. Amplifications were performed by an initial denaturation step of $94^{\circ} \mathrm{C}$ for 3 min, followed by 10 cycles of $94{ }^{\circ} \mathrm{C}$ for $15 \mathrm{~s}$, with a specific annealing temperature for each primer for $20 \mathrm{~s}$ and $72{ }^{\circ} \mathrm{C}$ for $30 \mathrm{~s}$. Subsequently, 25 cycles at $89^{\circ} \mathrm{C}$ for $15 \mathrm{~s}$, $53{ }^{\circ} \mathrm{C}$ for $20 \mathrm{~s}, 72^{\circ} \mathrm{C}$ for $30 \mathrm{~s}$, and a final extension at $72{ }^{\circ} \mathrm{C}$ for $30 \mathrm{~min}$ were performed. The polymerase chain reaction (PCR) products were identified using a MegaBACE automated capillary sequencer. Allele sizes were scored against the size standard ET 550R (GE Healthcare Life Sciences, Pittsburgh, PA, USA), and the peaks were analyzed using the MegaBACE Fragment Profiler program.

\section{Statistical analysis}

The Popgene version 1.32 program (Yeah et al., 1999) was used to calculate the following estimators of genetic diversity: allele frequency, expected $\left(\mathrm{H}_{\mathrm{e}}\right)$ and observed $\left(\mathrm{H}_{\mathrm{o}}\right)$ heterozygosity, genetic distance between populations (Nei, 1978), and F-statistics (Wright, 1978). For these statistical analyses, colonies were grouped according to locality, and each of these groups was considered to be a population.

Grouping analysis based on the UPGMA algorithm and the analysis of molecular variance (AMOVA; Excoffier et al., 1992) were carried out using the Genes program (Cruz, 2012). The cophenetic correlation coefficient that measures to which extent the clustering result corresponds to the original dissimilarity matrix was used to test the efficiency of the clustering analysis for the data (Rohlf and Fisher, 1968), and AMOVA was calculated considering two hierarchic levels and the groups formed in the clustering analysis.

\section{Results}

The nine microsatellite loci analyzed presented 65 alleles, ranging from three (Mquad24) to 15 (Mquad7) alleles (mean: 7.2 alleles/locus). All loci showed deviations from the Hardy-Weinberg equilibrium $(\mathrm{p}<0.05)$ at one or more sites, but no single locus showed deviations in all cases. Table S1 shows the allele frequencies observed for these loci, considering all the analyzed populations.

The most frequent alleles of the different loci were present in both populations of $M$. quadrifasciata quadrifasciata and M. quadrifasciata anthidioides, as well as in the populations with continuous metasomal stripes from northern Minas Gerais and Sergipe and in the hybrid morphotype from Bahia. In general, however, the populations exhibited different allelic constitutions, with some fixed and other private alleles (Table S2).

In the different analyzed populations, the observed heterozygosity $\left(\mathrm{H}_{\mathrm{o}}\right)$ ranged from $0.03-0.21$, while the expected heterozygosity $\left(\mathrm{H}_{\mathrm{e}}\right)$ ranged from $0.23-0.47$.

The genetic distances among populations ranged from 0.05 (Piranga and Rio Vermelho, Cristiano Otoni and Caeté, Cristiano Otoni and Urucuia) to 0.45 (Januária and São Cristovão) (Table 3).

Clustering analysis demonstrated that populations of both subspecies, although clustering together in a single 
Table 3 - Genetic distances among the fifteen Melipona quadrifasciata populations analyzed (codes are the same as in Table 1).

\begin{tabular}{|c|c|c|c|c|c|c|c|c|c|c|c|c|c|c|c|}
\hline Pop & PA & IÇ & $\mathrm{CT}$ & MP & $\mathrm{CO}$ & PI & $\mathrm{DM}$ & $\mathrm{CE}$ & $\mathrm{RV}$ & $\mathrm{PO}$ & $\mathrm{CA}$ & UR & JA & $\mathrm{SC}$ & OU \\
\hline \multicolumn{16}{|l|}{ PA } \\
\hline IÇ & 0.16 & & & & & & & & & & & & & & \\
\hline $\mathrm{CT}$ & 0.13 & 0.06 & & & & & & & & & & & & & \\
\hline $\mathrm{MP}$ & 0.18 & 0.17 & 0.15 & & & & & & & & & & & & \\
\hline $\mathrm{CO}$ & 0.14 & 0.18 & 0.11 & 0.14 & & & & & & & & & & & \\
\hline PI & 0.18 & 0.15 & 0.09 & 0.09 & 0.06 & & & & & & & & & & \\
\hline $\mathrm{DM}$ & 0.25 & 0.24 & 0.18 & 0.18 & 0.09 & 0.09 & & & & & & & & & \\
\hline $\mathrm{CE}$ & 0.17 & 0.20 & 0.14 & 0.21 & 0.05 & 0.07 & 0.07 & & & & & & & & \\
\hline RV & 0.19 & 0.09 & 0.07 & 0.14 & 0.13 & 0.05 & 0.18 & 0.13 & & & & & & & \\
\hline $\mathrm{PO}$ & 0.21 & 0.14 & 0.16 & 0.13 & 0.11 & 0.10 & 0.11 & 0.13 & 0.14 & & & & & & \\
\hline $\mathrm{CA}$ & 0.11 & 0.12 & 0.09 & 0.10 & 0.06 & 0.07 & 0.13 & 0.07 & 0.09 & 0.14 & & & & & \\
\hline UR & 0.15 & 0.22 & 0.16 & 0.18 & 0.05 & 0.06 & 0.13 & 0.09 & 0.12 & 0.11 & 0.13 & & & & \\
\hline JA & 0.24 & 0.13 & 0.16 & 0.15 & 0.13 & 0.09 & 0.15 & 0.19 & 0.11 & 0.10 & 0.18 & 0.11 & & & \\
\hline $\mathrm{SC}$ & 0.44 & 0.43 & 0.35 & 0.36 & 0.29 & 0.28 & 0.40 & 0.28 & 0.33 & 0.42 & 0.22 & 0.37 & 0.45 & & \\
\hline OU & 0.19 & 0.31 & 0.27 & 0.37 & 0.19 & 0.23 & 0.23 & 0.18 & 0.28 & 0.21 & 0.22 & 0.15 & 0.27 & 0.35 & \\
\hline
\end{tabular}

major group, can be divided into two subgroups, one containing the populations of the subspecies M. quadrifasciata quadrifasciata and the other the populations of the subspecies $M$. quadrifasciata anthidioides and the two $M$. quadrifasciata populations with continuous metasomal stripes from northern Minas Gerais (Figure 1). Only populations from São Cristovão and Ourolândia, which showed higher genetic distance values than the other populations (Table 3), were isolated in this analysis. The cophenetic correlation of this clustering was high (0.87), further showing a good adjustment between the genetic distances and the graphically represented distances.

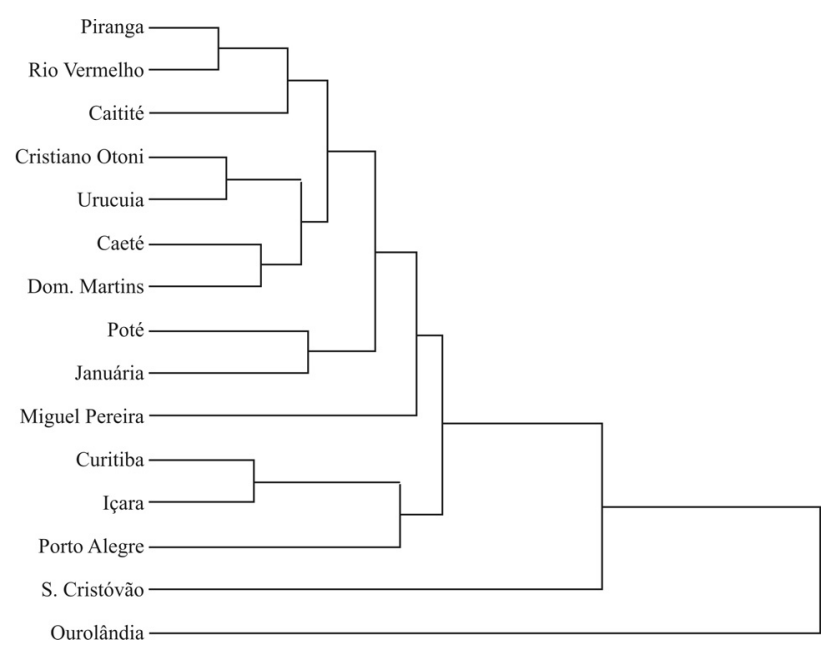

Figure 1 - Dendrogram based on the UPGMA method, showing the Nei genetic distances (Nei, 1978) among the Melipona quadrifasciata populations analyzed. Cophenetic correlation $=0.87$.
The $\mathrm{F}_{\mathrm{ST}}$ multilocus value obtained when populations of both subspecies were considered together $\left(\mathrm{F}_{\mathrm{ST}}: 0.23\right)$ also showed that they were structured, and the AMOVA test demonstrated that the interpopulation variation $(52.5 \%)$ was higher than the intrapopulation variation $(47.5 \%)$ of the subgroups obtained in the clustering analysis. Differences in the allele frequencies among populations as well as their private alleles probably contributed to these results.

\section{Discussion}

Our results showed a relatively high level of multiallelism in the nine microsatellite loci analyzed, which is characteristic when species-specific microsatellite primers are used (Peters et al., 1998; Paxton et al., 2003; Brito et al., 2009; Kapheim et al., 2009; Lopes et al., 2009a,b; Oliveira et al., 2009; Francisco et al., 2011).

This high number of alleles, however, was evidenced only when all populations were considered together. When each population was considered separately, only few alleles were found in each of the loci analyzed, always with one of them at a higher frequency. Consequently, a low frequency of heterozygotes was detected, which may explain the differences between the expected and observed heterozygosity values found. Additionally, despite having sampled 13 to 18 colonies in some localities, this sample size can be considered relatively small, which might also explain this difference, as well as the observed deviations from the Hardy-Weinberg equilibrium.

Notwithstanding, the lower level of genetic variability detected in the $M$. quadrifasciata populations (that gen- 
erally mate once) compared to the values reported for $M$. bicolor $\left(\mathrm{H}_{0}: 0.40\right.$, Peters et al., 1998) and Apis mellifera $\left(\mathrm{H}_{\mathrm{o}}\right.$ : 0.35-0.59, De La Rúa et al., 2003), for example, may be due to biological differences between the species, such as the facultative polygyny of M. bicolor (Cepeda, 2006; Velthuis et al., 2006), the multiple mating of honeybee queens (Estoup et al., 1994) or the limited flight dispersion distance of stingless bees (Araújo et al., 2004).

Although $M$. quadrifasciata presents a widespread geographic distribution, occupying distinct biomes such as the Atlantic rainforest, gallery forests (seasonal forests) and arborous caatinga, environment degradation may also be contributing to their reduced genetic variability. This hypothesis should be considered, as it was already observed in M. rufiventris and M. mondury populations (Tavares et al., 2007) that environmental degradation may isolate populations in small forest fragments, leading to inbreeding and local extinction. An indication of this local extinction is provided by Batalha-Filho et al. (2009) who, in contrast to Kerr (1951), found no M. quadrifasciata specimens in Pernambuco and Paraiba, despite intensive searching.

It is worthy of note that many of the private alleles detected in the present study were found in samples from Urucuia/Januária (northern Minas Gerais). Similarly, allele A of locus Mquad24 was found only in M. quadrifasciata population from São Cristovão (Sergipe) and in the hybrid population from Ourolândia (Bahia). As mentioned above, although the samples from Urucuia, Januária and São Cristovão contain $M$. quadrifasciata populations with continuous metasomal stripes, they were located completely outside the distribution area of $M$. quadrifasciata quadrifasciata.

Therefore, the presence of these private alleles is evidence of restricted genetic flow between these and the other populations of $M$. quadrifasciata anthidioides and could explain the genetic differentiation detected for the populations of São Cristovão and Ourolândia. Genetic differentiation among some $M$. quadrifasciata populations has also been detected using ISSR markers (Nascimento et al., 2010), PCR-RFLP assays of mtDNA (Batalha-Filho et al., 2009), and mtDNA COI gene sequencing (Batalha-Filho et al., 2010). According to these authors, geographic barriers separating close neighbors of this species can explain this differentiation.

The clustering analyses showed that $M$. quadrifasciata populations from Curitiba, Içara and Porto Alegre, which correspond to the subspecies $M$. quadrifasciata quadrifasciata, form a separate subgroup from the $M$. quadrifasciata populations of Urucuia and Januária, which exhibit a continuous metasomal stripe pattern similar to this subspecies, but are genetically more similar to M. quadrifasciata anthidioides populations.

The two other morphologically atypical $M$. quadrifasciata populations (São Cristovão and Ourolândia), however, were found to be isolated in the clustering analyses performed in this study. These same populations were clustered with $M$. quadrifasciata anthidioides in the phylogeographic study of Batalha-Filho et al. (2010), although the presence of exclusive haplotypes was detected in populations with continuous metasomal stripes from Sergipe. This result may represent differences between the two molecular markers used (mitochondrial vs. nuclear). In the present case, as microsatellites represent nuclear markers with a high mutation rate, the presence of two or three exclusive alleles was sufficient to differentiate populations. Further studies are necessary to elucidate the taxonomic status of these populations.

Overall, the results obtained in the present study corroborate those of previous studies demonstrating genetic differences between the two M. quadrifasciata subspecies (Waldschmidt et al., 2000; Moreto and Arias, 2005; Souza et al., 2008; Batalha-Filho et al., 2009, 2010). Additionally, as already observed by Batalha-Filho et al. (2009, 2010), our results also indicated that the $M$. quadrifasciata populations from northeastern Bahia and Sergipe are genetically different from the M. quadrifasciata quadrifasciata samples, even though they show the characteristic continuous metasomal stripes pattern.

\section{Acknowledgments}

The authors are grateful to the Fundação de Amparo à Pesquisa do Estado de Minas Gerais (FAPEMIG) for the financial support granted. We also thank Dr. Leonardo Lopes Bhering and Dr. Cosme Damião Cruz from Universidade Federal de Viçosa for statistical assistance with the GENES program. We also wish to thank Dr. Fabrício Rodrigues dos Santos from Universidade Federal de Minas Gerais for the help with sequencing analyses.

\section{References}

Araújo ED, Chaud-Neto J and Fowler HG (2004) Body size and flight distance in stingless bees (Hymenoptera, Meliponini): Inference of flight range and possible ecological implications. Braz J Biol 64:563-568.

Batalha-Filho H, Melo GAR, Waldschmidt AM, Campos LAO and Fernandes-Salomão TM (2009) Geographic distribution and spatial differentiation in the color pattern of abdominal stripes of the Neotropical stingless bee Melipona quadrifasciata (Hymenoptera, Apidae). Zoologia 26:213219.

Batalha-Filho H, Waldschmidt AM, Campos LAO, Tavares MG and Fernandes-Salomão TM (2010) Phylogeography and historical demography of the Neotropical stingless bee Melipona quadrifasciata (Hymenoptera, Apidae): Incongruence between morphology and mitochondrial DNA. Apidologie 41:534-547.

Brito RM, Francisco FO, Domingues-Yamada AMT, Gonçalves PHP, Pioker FC, Soares AEE and Arias MC (2009) Characterization of microsatellite loci of Tetragonisca angustula (Hymenoptera, Apidae, Meliponini). Conserv Genet Resour 1:183-187. 
Camargo JMF and Pedro SEM (2007) Meliponini Lepeletier, 1836. In: Moure JS, Urban D and Melo GAR (eds) Catalogue of Bees (Hymenoptera, Apoidea) in the Neotropical Region. Sociedade Brasileira de Entomologia, Curitiba, pp 272-578.

Cepeda OI (2006) Division of labor during brood production in stingless bees with special reference to individual participation. Apidologie 37:175-190.

Cruz CD (2012) Programa Genes: Aplicativo Computacional em Genética e Estatística. Versão Windows - 2012. UFV, Viçosa.

De La Rúa P, Galián J, Serrano J and Moritz RFA (2003) Genetic structure of Baleartic honeybee populations based on microsatellite polymorphism. Genet Sel Evol 35:339-350.

Estoup A, Solignac M and Cornuet JM (1994) Precise assessment of the number of patrilines and of genetic relatedness in honeybee colonies. Proc R Soc Lond B 258:1-7.

Excoffier L, Smouse PE and Quattro JM (1992) Analyses of molecular variance inferred from metric distances among DNA haplotypes: Application to human mitochondrial DNA restriction data. Genetics 131:479-491.

Francisco FO, Brito RM, Santiago LR, Gonçalves PHP, Pioker FC, Domingues-Yamada AMT and Arias MC (2011) Isolation and characterization of 15 microsatellite loci in the stingless bee Plebeia remota (Apidae, Meliponini). Conserv Genet Resour 3:417-419.

Freitas BM, Imperatriz-Fonseca VL, Medina LM, Kleinert AMP, Galetto L, Nates-Parra G and Queza-Eúan JJG (2009) Diversity, threats and conservation of native bees in the Neotropics. Apidologie 40:332-346.

Imperatriz-Fonseca VL, Saraiva AM and De Jong D (2006) Bees as Pollinators in Brazil: Assessing the Status and Suggesting Best Practices. Holos, Ribeirão Preto, 111 pp.

Kapheim KM, Pollinger JP, Wcislo WT and Wayne RK (2009) Characterization of 12 polymorphic microsatellite markers for a facultatively eusocial sweat bee (Megalopta genalis). Mol Ecol Res 9:1527-1529.

Kerr WE (1951) Estudos sobre a genética de populações de Himenópteros em geral e dos Apíneos sociais em particular. Tese para livre docência. An Esc Super Agric Luiz de Queiroz 8:219-354.

Kerr WE, Carvalho GA, Da Silva AC and Assis MG (2001) Aspectos pouco mencionados da biodiversidade amazônica. Parc Estrat 12:20-41.

Lopes DM, Silva FO, Fernandes-Salomão TM, Campos LAO and Tavares MG (2009a) Microsatellite loci for the stingless bee Melipona rufiventris (Hymenoptera, Apidae). Mol Ecol Res 9:923-925.

Lopes DM, Silva FO, Fernandes-Salomão TM, Campos LAO and Tavares MG (2009b) A scientific note on the characterization of microsatellite loci for Melipona mondury (Hymenoptera, Apidae). Apidologie 41:138-140.

Moreto G and Arias MC (2005) Detection of mitochondrial DNA restriction site differences between the subspecies of Melipona quadrifasciata Lepeletier (Hymenoptera, Apidae, Meliponini). Neotrop Entomol 34:381-385.

Moure JS and Kerr WE (1950) Sugestões para a modificação da sistemática do gênero Melipona (Hymen.-Apoidea). Dusenia 1:105-129.
Nascimento MA, Batalha-Filho H, Waldschmidt AM, Tavares MG, Campos LAO and Fernandes-Salomão TM (2010) Variation and genetic structure of Melipona quadrifasciata Lepeletier (Hymenoptera, Apidae) populations based on ISSR pattern. Genet Mol Biol 33:394-397.

Nei M (1978) Estimation of average heterozygosity and genetic distance from a small number of individuals. Genetics 89:583-590.

Oliveira EJF, Freitas GS, Fonseca AS, Sousa ACB, Campos T, Assis AF, Souza AP, Contel EPB and Soares AEE (2009) Isolation and characterization of microsatellite markers from the stingless bee Nannotrigona testaceicornis. Conserv Genet Resour 1:97-99.

Paxton RJ, Arévalo E and Field J (2003) Microsatellite loci for the eusocial Lasioglossum malachurum and other sweat bees (Hymenoptera, Halictidae). Mol Ecol Notes 3:82-84.

Peters JM, Queller DC, Imperatriz-Fonseca VL and Strassmann JE (1998) Microsatellite loci for stingless bees. Mol Ecol 7:784-787.

Rohlf FJ and Fisher DL (1968) Test for hierarchical structure in random data sets. Syst Zool 17:407-412.

Schuelke M (2000) An economic method for the fluorescence labeling of PCR fragments. Nat Biotechnol 18:233-234.

Schwarz H (1932) The genus Melipona IV. The type genus of the Meliponidae or stingless bees. Bull Am Mus Nat Hist 63:231-460.

Silveira FA, Melo GAR and Almeida EAB (2002) Abelhas Brasileiras: Sistemática e Identificação, Fundação Araucária, Belo Horizonte, 253 pp.

Souza RO, Moretto G, Arias MC and Del Lama MA (2008) Differentiation of Melipona quadrifasciata L. (Hymenoptera, Apidae, Meliponini) subspecies using cytochrome b PCRRFLP patterns. Genet Mol Biol 30:445-450.

Tavares MG, Dias LAD, Borges AA, Lopes DM, Busse AHP, Costa RG, Salomão TMF and Campos LAO (2007) Genetic divergence between populations of the stingless bee uruçu amarela (Melipona rufiventris group, Hymenoptera, Meliponini): Is there a new Melipona species in the Brazilian state of Minas Gerais? Genet Mol Biol 30:667-675.

Velthuis HW, De Vries H and Imperatriz-Fonseca VL (2006) The polygyny of Melipona bicolor: Scramble competition among queens. Apidologie 37:222-239.

Waldschmidt AM, Salomão TMF, Barros EG and Campos LAO (1997) Extraction of genomic DNA from Melipona quadrifasciata (Hymenoptera, Apidae, Meliponinae). Braz J Genet 20:421-423.

Waldschmidt M, Barros EG and Campos LAO (2000) A molecular marker distinguishes the subspecies Melipona quadrifasciata quadrifasciata and Melipona quadrifasciata anthidioides (Hymenoptera, Apidae, Meliponini). Genet Mol Biol 23:609-611.

Waldschmidt AM, Marco-Júnior P, Barros EG and Campos LAO (2002) Genetic analysis of Melipona quadrifasciata Lep. (Hymenoptera, Apidae, Meliponini) with RAPD markers. Braz J Biol 62:923-928.

Wright S (1978) Evolution and the Genetics of Populations. Variability Within and Among Natural Populations. University of Chicago Press, Chicago, 590 pp.

Yeah FC, Yang R and Boyle T (1999) Popgene ver. 1.32: Microsoft Windows-based freeware for population genetic analysis. Quick User Guide. 


\section{Supplementary Material}

The following material concerning this article is available online:

Table S1 - Allele frequencies of the microsatellite loci.

Table S2 - Distribution of the alleles present in the nine loci analyzed.
This material is available as part of the online article at http://www.scielo.br/gmb.

Associate Editor: Klaus Hartfelder

License information: This is an open-access article distributed under the terms of the Creative Commons Attribution License, which permits unrestricted use, distribution, and reproduction in any medium, provided the original work is properly cited. 
Table S1 - Alllelic frequencies of the nine microsatellite loci, estimated from fifteen populations of Melipona quadrifasciata

\begin{tabular}{|c|c|c|c|c|c|c|c|c|c|}
\hline \multirow{2}{*}{ Alleles } & \multicolumn{9}{|c|}{ Loci } \\
\hline & Mquad2 & Mquad4 & Mquad5 & Mquad6 & Mquad7 & Mquad13 & Mquad19 & Mquad20 & Mquad24 \\
\hline A & 0.587 & 0.009 & 0.005 & 0.053 & 0.036 & 0.018 & 0.050 & 0.128 & 0.046 \\
\hline B & 0.385 & 0.047 & 0.027 & 0.049 & 0.232 & 0.072 & 0.025 & 0.832 & 0.064 \\
\hline C & 0.014 & 0.009 & 0.082 & 0.062 & 0.201 & 0.005 & 0.021 & 0.004 & 0.889 \\
\hline D & 0.014 & 0.056 & 0.877 & 0.699 & 0.165 & 0.409 & 0.004 & 0.027 & \\
\hline$E$ & & 0.872 & 0.009 & 0.018 & 0.139 & 0.014 & 0.017 & 0.009 & \\
\hline$F$ & & 0.009 & & 0.106 & 0.093 & 0.392 & 0.092 & & \\
\hline G & & & & 0.004 & 0.026 & 0.045 & 0.013 & & \\
\hline H & & & & 0.009 & 0.016 & 0.045 & 0.008 & & \\
\hline I & & & & & 0.010 & & 0.013 & & \\
\hline $\mathbf{J}$ & & & & & 0.031 & & 0.721 & & \\
\hline K & & & & & 0.010 & & 0.038 & & \\
\hline $\mathbf{L}$ & & & & & 0.021 & & & & \\
\hline $\bar{M}$ & & & & & 0.010 & & & & \\
\hline $\mathrm{N}$ & & & & & 0.005 & & & & \\
\hline 0 & & & & & 0.005 & & & & \\
\hline
\end{tabular}


Table S2 - Distribution of the alleles present in the nine loci analyzed in the different populations of Melipona quadrifasciata. Codes correspond to those from Table 1. Private alleles are in bold

\begin{tabular}{|c|c|c|c|c|c|c|c|c|c|}
\hline \multirow{2}{*}{ Alleles } & \multicolumn{9}{|c|}{ Loci } \\
\hline & Mquad2 & Mquad4 & Mquad5 & Mquad6 & Mquad7 & Mquad13 & Mquad19 & Mquad20 & Mquad24 \\
\hline A & $\begin{array}{c}\text { SC, OU, } \\
\text { CA, PI, CO, } \\
\text { CE, RV, } \\
\text { PO, DM, } \\
\text { MP, JA, } \\
\text { UR, CT, IÇ, } \\
\text { PA }\end{array}$ & CE, IÇ & PO & $\begin{array}{l}\text { CO, JA, } \\
\text { UR, CT }\end{array}$ & $\begin{array}{l}\text { PI, CA, } \\
\text { PO, DM }\end{array}$ & CE, IÇ & $\begin{array}{c}\text { OU, CA, PI, } \\
\text { CO, CE, } \\
\text { PO, DM, } \\
\text { UR, CT }\end{array}$ & $\begin{array}{l}\text { RV, PO, } \\
\text { JA, UR, CT, } \\
\text { IÇ, PA }\end{array}$ & SC, OU \\
\hline B & $\begin{array}{c}\text { SC, OU, } \\
\text { CA, PI, CO, } \\
\text { CE, RV, } \\
\text { DM, UR, } \\
\text { CT, IÇ, PA }\end{array}$ & $\begin{array}{l}\text { CA, PI, CO, } \\
\text { RV, MP, } \\
\text { JA, UR, CT }\end{array}$ & $\begin{array}{c}\mathrm{CA}, \mathrm{CO} \\
\mathrm{CA}\end{array}$ & $\begin{array}{l}\text { PI, CA, RV, } \\
\text { UR, CT }\end{array}$ & $\begin{array}{c}\text { CA, PI, } \\
\text { CO, CE, } \\
\text { RV, PO, } \\
\text { MP, JA, } \\
\text { CT, IÇ, PA }\end{array}$ & $\begin{array}{l}\text { OU, CA, } \\
\text { RV, PO, } \\
\text { OU, CT }\end{array}$ & $\begin{array}{c}\mathrm{CO}, \mathrm{MP} \\
\text { UR }\end{array}$ & $\begin{array}{c}\text { SC, OU, } \\
\text { CA, PI, CO, } \\
\text { CE, RV, } \\
\text { PO, DM, } \\
\text { MP, JA, } \\
\text { UR, CT, IC, } \\
\text { PA }\end{array}$ & $\begin{array}{c}\text { CE, PO, DM, } \\
\text { IÇ }\end{array}$ \\
\hline C & CA, DM & $\mathrm{CO}, \mathrm{UR}$ & $\begin{array}{c}\text { OU, JA, } \\
\text { UR, CT, PA }\end{array}$ & $\begin{array}{c}\text { SC, OU, } \\
\text { PI, CO, CE, } \\
\text { RV, JA, CT }\end{array}$ & $\begin{array}{l}\text { OU, PI, } \\
\text { CO, CE, } \\
\text { RV, DM, } \\
\text { JA, UR }\end{array}$ & PA & PI, CE, JA & PI & $\begin{array}{l}\text { SC, OU, CA, } \\
\text { PI, CO, CE, } \\
\text { RV, PO, DM, } \\
\text { MP, JA, UR, } \\
\text { CT, IÇ, PA }\end{array}$ \\
\hline D & CE & $\begin{array}{c}\text { SC, OU, } \\
\text { CA, PI, JA, } \\
\text { CT }\end{array}$ & $\begin{array}{c}\text { SC, OU, } \\
\text { CA, PI, CO, } \\
\text { CE, RV, } \\
\text { PO, DM, } \\
\text { MP, JA, } \\
\text { UR, CT, IÇ, } \\
\text { PA }\end{array}$ & $\begin{array}{c}\text { SC, OU, } \\
\text { CA, PI, CO, } \\
\text { CE, RV, } \\
\text { PO, DM, } \\
\text { MP, JA, } \\
\text { UR, CT, IÇ, } \\
\text { PA }\end{array}$ & $\begin{array}{l}\text { CA, PI, } \\
\text { CO, CE, } \\
\text { PO, DM, } \\
\text { JA, UR }\end{array}$ & $\begin{array}{c}\text { SC, OU, } \\
\text { CA, PI, CO, } \\
\text { CE, PO, } \\
\text { DM, MP, } \\
\text { JA, UR, CT, } \\
\text { IÇ, PA }\end{array}$ & UR & OU, JA, CT & \\
\hline E & & $\begin{array}{c}\text { SC, OU, } \\
\text { CA, PI, CO, } \\
\text { CE, RV, } \\
\text { PO, DM, } \\
\text { MP, JA, } \\
\text { UR, CT, IÇ, } \\
\text { PA }\end{array}$ & PA & UR & $\begin{array}{c}\text { OU, PI, } \\
\text { CE, RV, } \\
\text { JA, UR, PA }\end{array}$ & $\mathrm{PI}, \mathrm{CO}, \mathrm{UR}$ & $\mathrm{CO}, \mathrm{UR}$ & PI & \\
\hline $\mathbf{F}$ & & sc & & $\begin{array}{c}\text { OU, PI, CE, } \\
\text { RV, DM, } \\
\text { JA, UR, CT }\end{array}$ & $\begin{array}{l}\text { PI, CO, } \\
\text { CE, PO, } \\
\text { UR }\end{array}$ & $\begin{array}{c}\text { SC, OU, } \\
\text { CA, PI, CO, } \\
\text { CE, RV, } \\
\text { PO, DM, } \\
\text { MP, JA, } \\
\text { UR, CT, IÇ, } \\
\text { PA }\end{array}$ & $\begin{array}{c}\text { SC, CA, PI, } \\
\text { CE, RV, } \\
\text { DM, MP, } \\
\text { PA }\end{array}$ & & \\
\hline G & & & & UR & $\begin{array}{c}\text { CA, CE, } \\
\text { MP }\end{array}$ & $\begin{array}{l}\text { OU, CA, } \\
\text { CE, DM, IÇ }\end{array}$ & CE, CT, PA & & \\
\hline H & & & & PI & DM & $\begin{array}{c}\text { OU, CA, } \\
\text { DM, JA, CT }\end{array}$ & CO, UR & & \\
\hline I & & & & & $\mathrm{CO}$ & & JA, PA & & \\
\hline$J$ & & & & & $\begin{array}{c}\text { SC, OU, } \\
\text { CA }\end{array}$ & & $\begin{array}{c}\text { SC, OU, } \\
\text { CA, PI, CO, } \\
\text { CE, RV, } \\
\text { PO, DM, } \\
\text { MP, JA, } \\
\text { UR, CT, IÇ, } \\
\text { PA }\end{array}$ & & \\
\hline K & & & & & RV & & JA, UR & & \\
\hline L & & & & & $\mathrm{OU}, \mathrm{CO}$ & & & & \\
\hline M & & & & & MP & & & & \\
\hline $\mathrm{N}$ & & & & & DM & & & & \\
\hline 0 & & & & & JA & & & & \\
\hline
\end{tabular}

